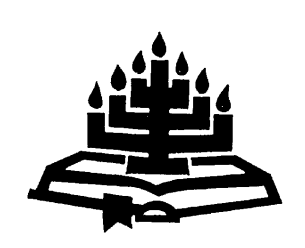

\title{
A theological view of environmental protection in Africa
}

\author{
K. Mwambazambi \\ Research Associate \\ Deptartment of Practical Theology \& Missiology "PRACTEMUS" \\ University of Stellenbosch \\ STELLENBOSCH \\ E-mail: profkalemba@yahoo.fr
}

\begin{abstract}
A theological view of environmental protection in Africa

African theologians, and indeed all humanity, should individually and collectively make a permanent commitment to environmental protection. Using conceptual tools as well as sociological and theological critical analysis, it can be demonstrated how closely such concepts as politics, economics, war, culture, technology, urbanisation, the Internet, globalisation, missiology, and theology are related to ecology and our natural environment. Consequently, African theologians and concerned people need to take into account, and observe ecological norms as part of the fulfilment of their world mission. Mugambi and Mika (2001:4) affirm that "human beings and nature as such are valuable and deserve to survive". Therefore, global and local role players must assume appropriate responsibility in order to ensure the necessary ecological balance to sustain life on this planet. This article analyses and demonstrates the importance of environmental protection of the African continent. The overall objective is to promote environmental awareness and active engagement in assessing the environmental impact on all human activities.
\end{abstract}

\section{Opsomming 'n Teologiese beskouing van omgewingsbeskerming in Afrika}

Afrikateoloë, en inderdaad die hele mensdom, behoort 'n permanente individuele en kollektiewe verbintenis tot omgewingsbeskerming te maak. Met behulp van konseptuele hulpmiddels, asook sosiologiese en teologiese kritiese analise, kan gedemonstreer word hoe konsepte soos politiek, ekonomie, oorlog, kultuur, tegnologie, verstedeliking, die Internet, globalisering, missiologie en teologie verband hou met die ekologie en ons 
natuurlike omgewing. Afrikateoloë en besorgdes behoort gevolglik ekologiese norme in ag te neem en waar te neem as deel van die vervulling van hulle wêreldsending. Mugambi en Mika (2001:4) verklaar dat "human beings and nature as such are valuable and deserve to survive". Globale en plaaslike rolspelers moet dus die toepaslike verantwoordelikheid aanvaar ten einde die noodsaaklike ekologiese balans te verseker vir die handhawing van lewe op hierdie planeet. Hierdie artikel analiseer en demonstreer die noodsaaklikheid van omgewingsbeskerming vir die Afrikakontinent. Die doel is om omgewingsbewustheid en aktiewe betrokkenheid in die assessering van die omgewingsimpak op alle menslike aktiwiteite aan te moedig.

\section{Introduction}

Climate change is a global environmental problem and while a developing continent like Africa has not contributed greatly to climate change, it will certainly be among those areas first affected by the impact of climate change (Pongo, 2008:7). By the close of this century, more than 180 million people will suffer the consequences of climate change in sub-Saharan Africa (Pongo, 2008:8). This is one of the reasons why it is so important to attack Africa's environmental problems head-on, both for present and future generations as well as the whole world. Africa must choose clean and renewable energy sources and take the lead in an energy revolution designed to reduce climate change. The Democratic Republic of Congo (DRC), one of Africa's many countries, can fight to protect the existence of the tropical forests under threat from industry. It is estimated that $40 \%$ of the Congo's forests will be lost within the next 40 years if nothing is done now (Ngonda, 2006:12). Africa must respond urgently and positively to fight the deforestation and land degradation that add to the problem of climate change. In addition, the impact of pollution caused by the industrialised nations constitutes an important threat to Africa and this, together with deforestation, has impacted negatively on the state of the environment on the continent. Obviously, international and internal factors have contributed to natural disasters in Africa owing to the causal connection between international capitalism, consumerism, liberalism, and pollution that plays such a deadly role in the destruction of the environment and natural habitats. It is impossible to ignore the effects of the global environmental crisis on human, animal and plant life in Africa. One of the essential substances to human and non-human lives is water. Today the availability of potable water is affected by many factors such as poor water and storage technology. Mugambi 
and Mika (2001:2) observe that "the life of large populations is compromised by the degradation of the environment caused by microeconomic and total practices of corporations". This is why it is necessary for African theologians to conscientise their people to fight environmental destruction in order to protect and steward the environment according to the vision of God. Writing further in connection to this, Mugambi and Mika (2001:4) advise that "the churches particularly can conscientise their people by the pastoral exhortation to protect nature". It will be an important force for good if theologians encourage African people to protect their environment according to the ordinances of God.

The most difficult to overcome is the intrusion of foreign nations in Africa because these nations exploit human greed for wealth. Foreign nations use the greed, the hunger and the "un"-health of Africa to gain a foothold here. African people need to apply ethical scientific knowledge for food production, to care for their environment by refusing to be polluting agents themselves, to live in a sustainable manner in accordance with the will of God and to avert the exploitation of Africa by foreign nations. Africans have to learn how to look after themselves in harmony with their neighbours. God has declared all creation good. Therefore, human beings should treat every part of creation as having its own intrinsic dignity (Moyo \& Ott, 2002:16). Africa still has time to choose for clean and renewable energy sources, and as a continent, should take the lead in an energy revolution designed to reduce climate change.

\section{Research background and development}

This reflection makes use of the descriptive method and comparative historical records. The major sources used are books, field surveys and other publications related to this research. If Africa is to have a vital and sustainable economy, it must guard against the fallout from ecological damage, as the health of the environment and the economy go hand in hand - like an inseparable couple (Pongo, 2008:14). Unwittingly, Africans have found themselves in danger from the food they are eating, the air they are breathing, and from the water they are drinking. This constitutes an unimaginable selfimposed threat and sanitary risk that could lead to human cataclysms of historical proportions - cataclysms that are avoidable if respect for the environment and responsible exploitation of natural resources were the norm (Ngonda, 2006:26). Rational and honest planning of how to exploit natural resources in Africa should thus be carried out as a paramount necessity. Accordingly Coste (2000:498) 
says, "the will of God is that human beings commune with nature as his/her intelligent and noble master and guardian, and not as his/her exploiter and destructor denuded of any management". That is why many rural Africans may consume less polluted food than many citizens of first world countries.

Industries, great powers and poor communities pollute and damage the natural world and there is no equitable and balanced stewardship of the environment according to God's will. Respecting his will requires taking values into account - especially ecological values such as environmental protection - the protection of soil, forests, flora and fauna. Fighting pollution, deforestation and erosion are necessary for the protection of the African people, for God meant them to lead a healthy life in a healthy environment. It is common knowledge that in most cases these ecological norms are often sabotaged by the very people who defined them, because deep within them, lies a huge and dangerous "love of money" (1 Tim. $6: 10)$. The DRC is a case in point. The soil, geological resources, flora and fauna are naturally rich. Those who best know how rich the $\mathrm{DRC}$ is, are the great economic, military and political powers of the world. The wealth of the country is exploited with such greed and violence that it has caused great human misery. Ruthless and cruel leaders who will best serve the interests of the foreign powers, are supported even though their leadership causes the impoverishment and death of their citizens.

Aware of such global abuses, Biber (2004:53) denounces "over-consumption and over-exploitation that deplete or dangerously diminish natural resources that God has given to human beings for proper management". In connection to this, Coste (2000:499) also remarks,

instead of fulfilling their role as collaborators of God in the work of creation, the economically strong people choose to take the place of God, ending up provoking the revolt of nature that is more tyrannized than governed by them.

If the African people want Africa to develop and prosper in peace, they must oppose anything that kills the continent. The African elite and theologians are a meaningful part of the spearhead in the struggle towards integrity and the protection of the environment. Indeed, every Christian should set an example to others and take the lead in their communities. 


\section{Overview of the causes of environmental degradation in Africa}

The purpose of this section is to provide an overview of the causes of environmental degradation in Africa and it is divided into three parts: the first part will focus on causes that spring from the political and economic arenas, from socio-cultural values, and from urbanisation. The second part will deal with biblical views on environmental protection, and the third part will focus on theological solutions to environmental protection.

\subsection{Politics}

At the mercy of political power, responsibility for the environment poses a challenge to Africans. The right or wrong actions of today will have serious repercussions for future generations. With the advent of globalisation, Africans need to develop a new concept of citizenship that transcends national and cultural frontiers; that locates itself at the crossroads of the economy and politics of North and South - that is, a democracy, understood as equality of all in dignity, having the right to take part in the political and socioeconomic life of the planet. Organised economic networks involved in the exploitation of raw materials or financial speculation extend their lures to the politicians who lead these countries and so gain access to cheap manpower and resources, and finally reduce the freedom of conscience and moral choice for the consumer. These circumstances will be best addressed if Africa reinforces its fundamental values such as tolerance, palaver, negotiation, hospitality without compromise, team spirit, universal unity, brotherhood, love for life, and the spirit of sharing and equitable reparation. The neglect of these values has cost Africa dearly and is the cause, moreover, of most of the conflicts the continent is experiencing. However, Coste (2000:499) states:

We have decided to oppose any policy that deals with a good that may be traded and that allows speculation at the expense of the poor, that dumps toxic waste in the soil and water, that favours exploitation, environmental destruction, or that prevents those who live directly on the land to be its true managers ... (translation from the French - KM).

The European Ecumenical meetings at Bale and Graz consider any continual and irreparable damages caused to creation as criminal. They consider, as Coste (2000:499) puts it, that "it is vital and urgent to understand that the resources of the land are to be shared with 
the future generations who will live tomorrow" and consequently pleads for "a new lifestyle". It is true that the road to improvement will be a long one. Nevertheless, theologians should continue to fight with determination and conscientise political leaders to make good decisions in support of environmental protection. As Sallie (2008:29) emphasises, there is a "political need to join the kind of human action in the world that will create a just and sustainable planet".

African people can again learn from creation and live in accordance with its laws (Berry, 2000:62). It may seem harsh to say that the goal of environmental protection ought to take precedence over feeding the malnourished and starving segments of a continent's population. This recommendation, however, should be seen in context of the necessity of protecting the very source of any equitable, culturally sensitive, as well as environmentally friendly and sustainable livelihood for those very people, namely the natural environment in its totality (Kakaire, 2008:9). It is essential to review ecological policy in Africa and rethink the national laws upon which we will build the foundation for a new ecological and moral norm. The lasting solutions to environmental protection in Africa do not only lie in emulating the best of alien (and all too often alienating) European systems and models, but the solution is rather in the active recovery and utilisation of Africa's previously immobilised cultural sensibilities, resource management skills, practices, moral values, and knowledge systems in connection with ecological matters. This is not to deny the importance of support from well-crafted legislation and the need to enforce such laws to manage and prevent environmentally harmful actions. Environmental organisations can do a great deal to encourage pro-environmental action, while environmental lawyers and poverty lawyers have much to do to address the disproportionate burden of pollution borne by low-income communities. An active campaign against deforestation is long overdue and reforestation is a matter of urgency. In the light of the responses to water pollution, Christian communities can play vital roles in ameliorating the unpleasant water or ecological problems in Africa.

\subsection{Economics}

Economics constitutes the leitmotif of the relationships and politics of states. Economic interests naturally seek lucrative market opportunities and to secure a dominant share or monopoly of the riches of the target country. Western countries supported Rwanda from the viewpoint that it offered useful economic access to the territory. It also served as a transit site for the exploitation of petrol, niobium, 
methane gas and minerals - not only from Mwanda, Goma, North Kivu and South Kivu - but also from the neighbouring Congo. Finally, it served as location for the creation of a thriving market for weapons. This economic imperialism played a role in who became the allies and who the enemies of the Congo-Hima-Tutsi. After the 1994 genocide and bloodshed in Rwanda and the DRC, these same Western business partners sought to distance themselves from any shared responsibility in the plight of those countries. Cirimwami (1999:374-376) points out that "the current Rwandan regime takes advantage of the genocide, to afford themselves whatever they can" - so this guilt is certainly shared. This situation challenges each African and the minority who claim to be the theological defenders of the creation. The solution to the infernal cycle of violence and xenophobia found in the wars mentioned above, lies in the dynamic search for sustainable peace. According to the Bible, such a dynamic peace is not only the absence of conflict or hostility, but to live in harmony with God and in community with one's neighbour and the nature. Along these lines, Martin Luther King quoted by Ngonda (2006:34), puts it as follows:

I have dreamed Lord, a world where prevails among humans, peace and not war, understanding and not misunderstanding, sharing and not selfishness, equity and not favouritism, light and not darkness, love and not hatred, true love and sincere loving.

It is true that war affects not only the whole ecosystem, but also the socio-cultural values of the African poor, theologians, and concerned people. Therefore, it is high time African theologians stand up to fight against the destruction of the African environment.

Global warming, the depletion of the ozone layer, the degradation of the soil due to deforestation, erosion, desertification, and the pollution of the water and atmosphere; are dangerous developments. Almost all of these phenomena are the outcome of human industrialisation in pursuit of economic interests without care for environment. Pestilence and sickness have been caused by household and industrial wastes and have lead to a proliferation of flies, mosquitoes, fleas, ticks, andrats which encourages the spread of malaria, cholera, diarrhoea and typhoid. In addition, overcrowding causes the spread of lung disease, and exposure to radioactive waste places the population at risk for cancer. Another factor is the biotechnological hazards associated with genetic modifications carried out in research laboratories and by the pharmaceutical industry (Pongo, 2008:25). The dissemination of genetically modified organisms in 
nature may have disastrous results for the planetary ecology and for humankind. The dissemination of genetically modified plants or animals can also worsen this situation. The challenges are bad housekeeping by humans, poor infrastructure, and overpopulated cities and towns. Ecological ethics are without doubt one of the most important socio-economic norms of the moment. A thorough understanding of consumer behaviour and the dangers of consumerism are prerequisites for environmental protection. It is necessary to rethink the way human settlements and activities interact with the ecosystem, to prevent the destruction of trees and to protect the savannahs from overgrazing.

\subsection{Socio-cultural values}

The Dictionnaire Oecuménique de Missiologie (2001:76) defines culture as a structured set of norms, rules, models, values and symbols shared among the members of the community. Kä Mana (1996:77) asserts that

it is by reference to the above system that any human conduct, ways of doing, acting, thinking, of judging and speaking express themselves and justify themselves as coherent, efficacious, acceptable or not in the sight of the community.

In its restricted sense, the term culture is used to describe a symbolic organisation of a group, of the transmission of this organisation and of all the values that support the representation of this group, as well as what it believes of itself and its relationship with nature. Djundu (2000:49) says that science uses the term culture to "describe customs, beliefs, tongues, ideas, aesthetic tastes, technical knowledge, organization of the total human environment, tools, habitat", and so on. Contrary to the past belief that some people are without any culture at all, it is commonly accepted nowadays that there is no people without culture. There is furthermore no hierarchy among cultures and it is unacceptable to speak of inferior or superior cultures. However, the existence of differences among cultures are commonly recognised today. It is specifically from this perspective that it is appropriate to disseminate a message concerning the environment, as it relates to African cultural differences. A European and an African, both from the DRC, may because of their cultural differences, behave differently towards the environment. The European will tend to throw an unwanted plastic bag in the waste bin, while the African will generally tend to drop it as litter outside the bin. Such environmentally unaware behaviour and the increased insalubrities since the 1990s, have seriously contributed to the degrada- 
tion of the ecological system. One finds piles of waste and refuse including human excrement mixed with urine - almost everywhere: on certain street corners, in the marketplaces, schools, hospitals, churches, et cetera. This neglect is a danger to public health - the lack of infrastructure for refuse disposal and sanitation places the people at risk of contracting life-threatening and avoidable diseases such as typhoid, diarrhoea or cholera. Pollution of the soil, water and air, as well as soil erosion further threaten the health and livelihood of the people.

In the DRC, for example, water is continuously and progressively polluted by the numerous wastes related to human settlement, which includes an increasing number of old, rusty pipes leaking pollutants into the water system. Household wastes are thrown into water points and rivers, and water-borne diseases have multiplied. Yet, this situation does not seem to concern the political authorities or those in charge of water distribution. The soil erosion in Kinshasa, the capital city of the country (at Mbuji-Mayi and Bandundu), has numerous causes that includes anarchic construction that observes no urban or safety norms, blocked storm-water drains all over the city that can no longer control the torrential rain water typical of this region, and the aggressive deforestation of the rural environment. The soil erosion at Mataba (Ngaliema) is one of the most dramatic examples. Humans need salutary air to live a healthy life, however, the air is increasingly polluted with dust, smoke from bush fires, household woodfires, vehicles, and a few factories giving off fumes. Unsanitary odours and even weapons of war have all contributed to a certain level of air pollution with very negative consequences for the quality of life. This is a culture that might benefit from being examined in the light of the gospel, which is why African theologians have to raise awareness among Africans from different walks of life and relevant institutions to help. Such awareness of the need to protect the environment is important because the environment can play an important role, for or against, the Christian mission on the continent. Accordingly Tron (1999:13) states:

Nature has a role to play and secretly fulfill all around us if humans will leave her a little bit of space. Polluted and damaged places are good only for rats and pests; but if we give her a chance to settle in a favourable space, we will see flowers, singing birds and butterflies reappear for the joy and wonder of all, and first and foremost, of our children. I therefore claim the environment and blossoming of all trees for our lungs, flowers for our smiling and birds for our dreams. (Translation from the French - KM.) 
The statement above makes a convincing argument that humans can still take profit of the environment when they treat it with respect and work with it in a harmonious way. Unfortunately African people sometimes use techniques and technologies that hurt and scar nature. It is high time for African theologians to partake in raising awareness about this situation.

Humans generally use techniques and technologies to exploit nature in order to produce goods that satisfy their direct needs. The first of these techniques are based on the use of fire. African people have been using fire since the most ancient times in the process of production, from small-scale production to heavy industries. The production of these necessary energy sources has entailed a host of pollutants resulting from combustion. In a world where progress is based on a set of complex national and international economic relationships, the disturbances man causes to the environment could lead to insecurity and provoke unprecedented disorder and suffering - not only through the use of nuclear weapons, but also of nuclear powered stations. This can cause serious consequences today and tomorrow, not only for Africans who sometimes allow Westerners to dump nuclear waste in their countries expecting to receive economic benefits (something which often fails to happen), but also to humankind at a global level. Such hazards can be due to a mere accident or to the accumulation of radioactivity because of nuclear waste-dumping. It has dire consequences for the planet when the ozone layer is damaged by CFC, and the atmosphere warmed due to greenhouse gases such as carbon dioxide, methane and diverse other chemicals (Ngonda, 2006:11).

\subsection{Urbanisation}

Urbanisation is a universal phenomenon. Black African urbanisation is an important phenomenon that symbolises and favours the passage of the African populations from the traditional lifestyle to the modern one. Originally, and generally speaking, there are three types of cities in black Africa: cities developed out of economic drives such as Akran in the sixteenth century or Lomé in the eighteenth century; cities developed thanks to African intellectuals and colonial actions (Ngonda, 2006:3); or cities developed due to industrialisation such as Upoto in Equator or Maniema and MbujiMayi in the DRC. Most of the inhabitants of these cities came from the rural villages in order to improve their living standards in the cities and towns. This unplanned rural exodus creates new and complex problems such as joblessness, homelessness, over-popu- 
lation, and chaotic construction and housing that often lead to sociopolitical abuse and lawlessness. Lawlessness and anarchic construction generally give way to ecological abuse and soil erosion due to rain water that cannot be easily controlled. Accordingly De Witt $(1995: 13)$ states:

The immensity of this destruction clearly indicates how big is our ability to impair the face of the soil, to destroy forests we never plant, destroy the species that have not been indexed yet, convert them into plywood and toilet paper, to rear more cows on deforested lands meant for hamburger meat, to destroy what can support the life of the soil, animals and humankind for the years to come. In the USA entire regions have been deforested and fauna destroyed to clear space for parking, erecting buildings and houses, offices and churches.

This last point brings us back to what was happening in Kinshasa, capital city of the DRC, where extensive building of houses has occurred, even in dangerous and unsuitable places. These swampy areas have already taken numerous human victims and caused considerable material loss during torrential rains. Such anarchic building construction needs to be re-examined by competent urbanisation authorities in order to avoid more unfortunate losses in future. The populations living in such areas must be heedful not to risk their precious lives and the loss of their belongings; they must also be very careful to run from such places whenever warnings of torrential rains are issued.

The Internet is an interactive and gigantic network of communication and information exchange, capable of carrying impressive volumes of information through connected computers at high speed. Generally speaking, the information circulated through this network is characterised as follows:

- Polymorphic: that is to say that the information can take many forms - be it sound, a clear image, a moving image, a text, the result of an information technology process or a file;

- Ubiquitous: quasi-simultaneously, the given information can be available and accessible for any connected user throughout the world depending on the performance and speed of the computer used.

In fact, considering that nowadays development is not possible for a country that lives in a "closed circuit", cut off from the rest of the world, the Internet is like an open window on the world, an interface 
of giving and receiving. Mwenze (1998:126-127) comments that although the Internet "is a new tool that our communities are still striving to get used to, and a tool from a different culture, its use is very important to us". Among these advantages is that this technology allows easy access to useful information in the field of medicine and health, commerce and business, education and training, and from many other domains. As far as ecology and disaster prevention are concerned, the Internet can be of real assistance to the prevention of catastrophes, access to ecological education; as well as useful information - to limit both human and material losses due to ecological disasters. Information provided by volcano specialists, if used, can warn local people to move away or stay away from dangerous areas such as the Nyiragongo Volcano. Many people have lost their lives because they were not informed in time and the population on site is often caught unawares by calamity.

\section{Biblical views on environmental protection}

According to the Word of God, as written in Genesis (1:1, 31), God is the "creator of all things" and all creations are in him. God saw that all of his creation was good before giving its stewardship to humankind. Unfortunately, humanity chose to disobey him and to harm their environment. Along these lines Fihavango (2001:93) asserts: "the fall caused an imbalance in the equilibrium of the creation. The problem was transferred from the broken relationship with God to nature." Psalm 23:1-2 shows how the generosity of God "provides the good life in the nature". However, the man and woman created in the image of God, sinned and became malicious towards God and nature. Consequently, they lost the privilege of a direct relationship with God.

Genesis 3:14-24 affirms that the man and woman lost the blessing of being "co-governors" with God over creation and the seeds of their rebellion damaged the relationship between humans and nature. The fact that humans sinned against God destroyed the plan of God for humanity. However, Bujo (1998:214) considers that "by Christ, the whole creation hopes for a new life in abundance and close relationship with God". By contrast Kyomo (2001:58) remarks that "it is the responsibility of every individual to preserve this life which is represented by the living and non-living". This safeguarding is apparent in environmental protection. The reason why every Christian should show the African people the importance of protecting nature, is that the power and the glory of God are also manifested in the cosmos through trees, rivers, mountains, rocks, 
forests, animals, birds, et cetera. All creation speaks a divine language that proclaims the fear and the veneration of God. Abundant life is enjoyed only through the reconciliation of the whole cosmos with God. The community of the living and dead is also implied in the remedy provided by this reconciliation. Bujo (1998:209) underlines this fact by stating that "the human person and cosmos are supplemented at such a point that they cannot exist without this interdependence". Biblically, God imbues all his creatures with his presence. This is why it is necessary to protect nature, as God protects his people and works for the welfare of all. Therefore, we must not treat any of his creatures (any element, plant or animal) recklessly but deal with them in a sensitive manner, with empathy and reverence. The one who harms a creature, harms God Himself. The forest is as important as the skin of a human which, if removed, results in death. Death is at earth's door. Theologically, this appeal concerns all the African Christians to popularise and work towards environmental protection. According to Bookless (2008:41),

the creation is not our plaything or even our playground, but has intrinsic value to God and has immediate theological implications. Our use of natural resources in our lifestyles and our travel should be with restraint and respect.

Such an attitude is founded upon Christ's teaching in Matthew 6:2630 about God's providential "care for all creatures". Accordingly Bujo (1998:219) affirms that "the onus is on all the Christians to join in order to save our environments of the destruction". Ecological healing is only possible if Africans completely examine their relationship with nature. Every Christian should therefore conscientise the African people to protect Africa against all forms of environmental destruction and any form of ecological crisis, because by protecting the environment, they protect themselves. Theologians, through the Christian mission, can valuably accomplish this task because the Christian mission has the power to attack the causes of environmental destruction. Especially if they are well understood and contextualised according to the need of the people, i.e. food security, and by putting Christ at the centre of all things. African people have to take responsibility for their actions, as well as the problem of overpopulation. Theology has a mission to awaken Africans and to point out their responsibility towards God and God-created nature. Biblically, it is necessary to understand the environmental crisis as a great "pastoral challenge in Africa" (Kyomo, 2001:57).

Theologically, all creation, as the work of God, is sacred. Again, after the death and resurrection of Jesus Christ, there is no longer 
anything profane in the absolute sense. Every part of creation is saved in Christ, including nature. Hence, all the churches - not only the Catholic Church in their conviction that the whole of creation is saved in Christ, and that God is the maker of everything that lives in creation - should be the vanguards for the protection of nature. Apparently the church has always considered the proclamation of the gospel as its first mission, but it should no longer preach the gospel to human beings as though they were angels living divorced from the natural world. The church should consider the protection of the environment in which people live as an important part of their mission. The protection of the environment in which humans live should be taken seriously as part of the struggle for the restoration of the creation of God. So, the whole church has thus to speak of this matter with one voice.

\section{Theological solutions to environmental protection}

The reality of environmental degradation has also challenged theologians to rethink Christian missions and traditions with open minds and an attitude of humility (Foster \& Shreeve, 2008:2). The environmental crisis is a theological problem. Sallie (2008:31) argues it is "a problem coming from views of God and ourselves that encourages or permits our destructive, unjust actions". Whether one is a Christian or not, the earliest understanding of humanity and its relationship with nature had a religious foundation and a theological base. As for monotheistic religions, humankind is the centre of the world. After creating human beings in his likeness, God placed them outside nature and gave them the power to rule over it as a whole. Polytheist religions consider humankind as a product of nature, while the so-called "primitive" and Oriental religions consider humankind as only one form of life among many others. From this, different theological worldviews have emerged.

Theologically man and nature have a theological foundation insofar as God is the Creator of the world and humanity is at the centre of all. Missiologically, after creating human beings in his likeness, God gave them the authority to dominate his creation. The dominion and protection of the creation of God imply all aspects of the human life including the environment. The interdependence of all the creatures under the sun is a central discipline. Accordingly Kyomo (2001:63) affirms "life is worthy of life when this discipline becomes the currency for each human being". This interdependence between human beings and nature is given great consideration in the African design because the African regards nature as part of his existence accord- 
ing to the will of God. Niwagile (1997:174) is of the view that "the African people should be completely comfortable with this crucial heritage". This causes Africans to answer the call to environmental protection positively and supportively. Njah (2001:74) explains the operative conditions, saying "according to the attitudes and the values of the individuals and the communities towards their habitat".

Every Christian can hence "provide control and encourage associations to care for the environment by inspiring, informing and allowing ... people to improve their quality of life without compromising the lives of future generations" (Njah, 2001:78). Christians should bring the church back down to earth because the church should be ecological.

Christ is life, and the source of life for the whole creation. Life is the quality needed for true existence in the kingdom of God; without Christ, there is no life. This life in Christ is expressed through his creation. Unfortunately, while Christ brings abundant life to his creation, many people and the evil powers who direct the world, try to work with criminal negligence towards the destruction and reduction of the environment's value. All of life is sacred because it has its source in God through Christ. African theologians should therefore continuously re-examine the behaviour of the African people in relation to God as far as environmental protection is concerned. This will stimulate responsible behaviour and respect for God and his creation. God never gave us a mandate to destroy Africa. On the contrary, He entrusted Africans with the mission of protecting the environment. Acknowledging this connection, Mugambi and Mika (2001:125) observe that "from a theological point of view, we are all culprits and victims at the same time. We are culprits in the eyes of our fellow human beings and God when we participate in the destruction of the nature." This quotation is manifestly eloquent about God's will for his creation. It points straight to Africa's responsibility. In Mark 4:30-32, in the parable of the "mustard seed", Christ shows that God transferred the responsibility to protect all creatures to man. However, the example of the young rich man in Mark 10:17-22 seems to show that the "young rich man" was irresponsible in his daily behaviour by refusing to put God first. That is why every Christian theologian should revitalise the Christian mission by showing that total obedience to God in the protection of the environment is required if Africa wants to live an abundant life in accordance with the vision of God.

Mugambi and Mika (2001:29) affirm that "clearly the guiding principle of equity is central to the Biblical tradition. God's inheritance is 
for the communal body, a concept that includes all of nature". The goal of the protection of the environment is to support the health of humankind and the animal kingdom. However, the threat of climate change challenges all Africans to seek ways to stabilise the concentrations of carbon dioxide in the atmosphere. A future of noncarbon energy is a necessity and realisable possibility. Mugambi and Mika (2001:14) add that "we can make changes in the way that we live which will help to create healthy and sustainable communities". African theologians should ensure that Christian mission conscientises Christians about environmental concerns, in alignment with gospel-based living, and exercise the prophetic voice of the church to support appropriate environmental action.

However, Africa must stop polluting the soil, water and atmosphere if only for her own sake. The Christian faith communities and awareness campaigns can serve to enlighten the people on their demand for fresh water supply and the atmosphere, and call the governments' attention to its social responsibility of protecting the environment. A tree-planting campaign is also necessary.

\section{Conclusion}

The above analysis has taken a theological view of environmental protection in Africa and it must be said that all Christians, including theologians, can play an important ecological and socio-economic role in the lives of the African people. The goal of a new environmental ethic is nothing less than a matter of life and death (if not for our generation, then for those who will follow).

The environmental problems of Africa cannot be resolved only by appropriating insights emanating from the anthropocentric approach. The ruling elites are major players in the perpetuation of some of Africa's most desperate environmental problems. This article concludes with suggestions to enhance the quality of life. These include the training of African peoples on ecological norms. Christians, however, have a responsibility to serve as the conscience of communities and leadership when the welfare of the populace is sacrificed for minority interest. Efforts must therefore be made, by both the Christian faith communities and the other interested parties, to stop the environmental pollution.

In the presence of humanity's reckless and irresponsible actions against the creation of God, modality and solidarity can help us to master the global environment in a spirit of responsibility and partnership with God. This responsibility and partnership entail to 
managethe creation that God has put at the disposal of humankind. It is important to encourage people to calculate their own carbon footprint and to take steps to reduce it. The goal of the protection of the environment is to support the health and well-being of humankind as well as the rest of nature's inhabitants and their habitats.

\section{List of references}

BERRY, R.J. 2000. The care of creation: focusing concern and action. Downers Grove: InterVarsity.

BIBER, P. 2004. Mission et environnement. Burundi: Academie Panafricaine.

BOOKLESS, D. 2008. Christian mission and environmental issues: an evangelical reflection. Mission studies, 25:37-52.

BUJO, B. 1998. The ethical dimension of community: the African model and the dialogue between North and South. Nairobi: Paulines.

CIRIMWAMI, M. 1999. La paix aux enchères de la convoitise: autopsie d'une situation. Kinshasa: Cepas.

COSTE, R. 2000. Les dimensions sociales de foi. Paris: Cerf.

DEWITT, C. 1995. Sept dégradations de la création. Québec: La Clairière.

DICTIONNAIRE OECUMENIQUE DE MISSIOLOGIE. 2001. Paris: Cerf.

DJUNDU, N. 2000. La sociologie. Kinshasa: Centre Universitaire de Missiologie.

FIHAVANGO, G. 2001. Quest for ecotheology in a situation of ecological disaster. (In Mugambi, J.N.K. \& Mika, V., eds. Christian theology and environmental responsibility. Nairobi: Acton. p. 90-95.)

FOSTER, C. \& SHREEVE, D. 2008. Don't stop at the lights: leading your church through a changing climate. London: Church House.

KÄ MANA, K. 1996. Pour l'éthique de la vie: Bible, écologie et reconstruction de l'Afrique. Yaoundé: Clé.

KAKAIRE, K.M. 2008. Environmental challenges in Sub-Saharan: possible solutions. Florida: Boca Raton.

KYOMO, A. 2001. The environmental crisis as a pastoral challenge in Africa. (In Mugambi, J.N.K. \& Mika, V., eds. Christian theology and environmental responsibility. Nairobi: Acton. p. 57-63.)

MOYO, F. \& OTT, M. 2002. Christianity and the environment: care for what you have been given. Blantyre: Claim.

MUGAMBI, J.N.K. \& MIKA, V. 2001. Christian theology and environmental responsibility. Nairobi: Acton.

MWENZE, C. 1998. Science, technologie, communication et mondialisation. Kinshasa: Loyola.

NGONDA, J. 2006. Dieu est la création selon la Bible. Kinshasa: Med.

NIWAGILE, W. 1997. Our struggle for justice, peace and integrity of creation. (In Mugambi, J.N.K., ed. The church and reconstruction of Africa. Nairobi: AACC. p. 174-182.)

NJAH, P.T. 2001. Responding to global warming: an experience in Cameroon. (In Mugambi, J.N.K. \& Vähäkangas M., eds. Christian theology and environmental responsibility. Nairobi: Acton. p. 74-81.)

PONGO, M. 2008. Mondialisation et culture. Mbuji-Mayi: Smen.

SALLIE, M. 2008. A new climate for theology: God, the world, and global warming. Minneapolis: Fortress. 
TRON, F. 1999. La nature à-t-elle une place auprès de l'homme. Yaoundé: Cipcre.

\section{Key concepts:}

Africa, environmental protection

Christian mission environmental protection

theologians, responsibility

\section{Kernbegrippe:}

Afrika, omgewingsbeskerming

Christelike sending omgewingsbeskerming

teoloë, verantwoordelikheid 